\title{
Financial Capability of Accounting Students in South African Universities
}

\author{
Bomi Nomlala ${ }^{1, *}$ and Mabutho Sibanda ${ }^{2}$ \\ ${ }^{1}$ Auditing, College of Law \& Management Studies, University of KwaZulu-Natal, Durban, South Africa \\ ${ }^{2}$ Finance, College of Law \& Management Studies, University of KwaZulu-Natal, Durban, South Africa
}

\begin{abstract}
This study surveyed 1582 students studying Accounting degrees at universities in South Africa to assess their financial capability levels and intra-component drivers of financial capability. The study utilised statistical methods such as structural equation modelling technique was used to determine drivers of financial capability; regression analysis was further done to examine relationships between the students' mean percentage scores and their socio-demographic factors. The findings of the study suggest that accounting students are highly financially capable. It was further found that financial capability is driven by financial attitude; financial behaviour, and numeracy skills of the accounting students. In addition, the study found education, level of study, and race as statistically significant and socio-demographic influences of financial capability. This study suggests that financial capability can be further improved via improvements in financial attitude, financial behaviour, numeracy skills and education among racial groups in South Africa.
\end{abstract}

Keywords: Financial capability, financial behaviour, financial knowledge, financial attitude, Numeracy skills, accounting students.

\section{INTRODUCTION}

There is a continual global call for improved financial literacy among nations in order to improve financial behaviour and avoid such crisis as the global financial crisis. The World Bank defines financial capability as an individual's capacity to behave in their best financial interests, given socio-economic conditions. It encompasses the knowledge (literacy), attitudes, skills and behaviours of consumers in managing their resources, and understanding, selecting and making use of financial services that meet their needs (Zottel, 2013). In their study on the financial capability of low-income millennials, West and Friedline (2016) define this concept as an individual's ability to adopt healthy financial behaviours in an institutional context with opportunities that facilitate such behaviours. The authors further identify financial knowledge and financial inclusion as the two foundational pillars of financial capability. Consequently, Sherraden et al. (2015) are of the view that being financially capable helps individuals to accumulate the financial assets that are necessary for their long-term financial security.

From a broader perspective, financial capability plays a vital role in financial stability, financial inclusion and the effective functioning of financial markets (Zottel, 2013; Lusardi and Mitchell, 2014). It is also a

*Address correspondence to this author at the Auditing, College of Law \& Management Studies, University of KwaZulu-Natal, Durban, South Africa; Tel: +27312608603; E-mail: nomlalabc@ukzn.ac.za

JEL: G2, G4, M4, A20, D14, E2 vital ingredient in promoting financial stability at the household level (Lusardi, 2011; Sherraden, 2013). It is for this reason that it has received increased attention from governments and policymakers in both developing and advanced economies (Lusardi and Mitchell, 2014). Lusardi (2011) suggests that financial capability can be measured from the perspective of how households make financial decisions such as making ends meet, budgeting and choosing and managing financial products as well as having the requisite skills and knowledge of financial matters. Financial capability also improves financial stability by curbing growing economic inequalities among households (Sherraden, 2013).

This study surveyed accounting students in universities within the KwaZulu-Natal province of South Africa. The core inquiry of this study was to ascertain the levels and intra-component drivers of financial capability (financial knowledge, financial attitude, financial behaviour and numeracy skills) among accounting students at universities in South Africa with a focus on the KwaZulu-Natal universities. Within this perspective, the objectives of this study were to: (1) establish the levels of financial capability (financial knowledge, financial attitudes, financial behaviour and numeracy skills) among accounting students at universities in KwaZulu-Natal, (2) determine the intracomponent drivers of financial capability among accounting students at universities in KwaZulu-Natal, (3) evaluate the relationship between financial capability and the students' socio-demographic characteristics (4) provide empirical evidence that is 
relevant to the development of strategies necessary to improve the financial capability of the students.

The next section covers both the theoretical and empirical literature on financial capability, followed by the research methodology, the findings and results of the analysis. The final section contains the conclusion reached based on the study findings.

\section{LITERATURE REVIEW}

The capability approach is a broad normative framework that facilitates the evaluation and assessment of the well-being of individuals in social contexts (Robeyns, 2005; Sherraden et al., 2015). This framework is necessary for the formulation of policies and implementation of social change within society (Robeyns, 2005). As a normative rather than an explanatory theory, the capability approach is not designed to explain inequality, poverty, or individual well-being, but rather to conceptualise the notions therein (Robeyns, 2016). The term capability was developed in the seminal work of distinguished philosophers Amartya Sen and Martha Nussbaum. Winner of the Nobel Prize in Economic Sciences in 1998, Sen (1987) conceptualised capabilities as notions of freedom which are illustrated in presenting individuals with real opportunities to lead the type of life they want. He clarified that the normative crux of the capability approach could be understood in the following ways (Robeyns, 2016) (1) The assessment of individual well-being; (2) The evaluation and assessment of social arrangements; (3) The design of policies and proposals about societal social change.

Nussbaum (2000) examined how capability affects human development and individual welfare within a social context. This combined capability approach is made up of both internal capacity as well as external conditions. While internal capabilities comprise of an individual's skills set, knowledge and ability, external capabilities consist of a plethora of opportunities available to such individual in the form of access to products, institutions and services within society (Sherraden et al., 2015). Nussbaum (2000) added that the combined capability approach provides a platform of opportunities to all individuals within society via policies, laws, regulations and welfare incentives that improve the general well-being of individuals in society. The general capability approach comprises of two clusters that depict individual capability and commitment to a set of five principles, namely (Nussbaum, 2011) (1)Treating each person as an end;
(2) A focus on choice and freedom instead of achievements; (3) Pluralism about values; (4) Being deeply concerned about social justices; and (5) Ascribing an urgent task to the government.

In contextualising the capability approach from the perspective of financial capability, Sherraden et al. (2015) are of the view that financial capability is both an individual and structural idea, as the approach emphasises the environmental factors that influence individual capability. In a similar vein, (Johnson and Sherraden, 2007; Sherraden et al., 2015) regard financial capability as the fusion of an individual's ability to act, coupled with their opportunity to act in their best interests. Hence, financially capable individuals are not only financially literate but also have access to beneficial financial products and services that contribute to their financial functioning, well-being and life chances (Sherraden et al., 2015).

Zottel (2013) asserts that financial capability encompasses the financial knowledge, financial attitudes and skills as well as the financial behaviours of consumers with regard to managing their resources, and understanding, selecting and making use of financial services that meet their needs. Moreso, It has been said that financial capability can improve both financial decision making as well as access to suitable financial products and services, which are the two defining elements of financial inclusion (Mitton, 2008). This view is in consonance with the combined capability approach, which posits that both internal capacity and external conditions affect the capability of individuals (Nussbaum, 2000). Hence, financially capable individuals are not only financially literate but also have access to financial products and services that contribute to their financial functioning, well-being and life chances (Sherraden et al., 2015).

Loke et al. (2015) suggest that the youth's financial capability can be improved via financial education programmes. Their study surveyed 275 economically disadvantaged youths who participated in the MyPath Savings Initiative, a youth development and employment programme that encourages first income earners to save through traditional financial products. The study found that improvements in financial capability are not related to socio-demographic factors such as race, age, gender, household income, etc. (Loke et al., 2015).

Some studies have established a link between financial knowledge and financial capability (Brown et 
al., 2014; Drever et al., 2015; Xiao and O'Neill, 2016; Xiao and Porto, 2017). For instance, Xiao and O'Neill (2016) investigation of the impacts of financial education on the financial capability of Americans, found that consumers who are financially knowledgeable exhibited better financial capability. However, some authors have argued that financial knowledge is not sufficient to guarantee positive financial behaviour among young adults and that parental influence as well as self-discipline, are key determinants of positive financial behaviours (Tang and Peter, 2015; Friedline and West, 2016).

On the other hand, several recent studies have found low levels of financial knowledge among college students (Jayakumar et al., 2017; Andreou and Philip, 2018; Brooks and Wheeler, 2018; Anderson et al., 2018), others have suggested that these students have good financial knowledge (Sarpong-Danquah et al., 2018). Jayakumar et al. (2017) cross-sectional survey of first- and fourth-year students across seven American medical schools found that the students were not financially knowledgeable, despite the provision of financial counselling for the fourth-year students. Sarpong-Danquah et al. (2018) investigated the level of financial literacy among students across tertiary institutions in Ghana. The study sampled 480 students via a self-administered questionnaire. It was found that the majority of the students were highly knowledgeable about savings and investment-related issues but had little knowledge of insurance. The authors recommended the inclusion of financial education programmes in tertiary curricula, regular seminars to promote financial awareness and the use of digital platforms to improve students' financial knowledge.

In terms of spending and credit, Chmelíková (2016) confirmed that students' experience of loans was a key determinant of their debt behaviours. Americans across all age groups have low levels of debt literacy (Lusardi and Tufano, 2015; Brown et al., 2016). This is worrying as sparse knowledge of how debt works tend to result in bad decisions (Lusardi and Tufano, 2015). Brown et al. (2016) assert that poor debt behaviour among young American students is a result of their poor financial capability. Financial knowledge can prevent poor debt choices as well as being vulnerable to financial scams (Andreou and Philip, 2018).

Harrison et al. (2015) qualitative study on debt attitudes among young university students in England, found that only a third of the students believed that managing their day-to-day expenses is pivotal to controlling and minimising their debt. Manju (2016) survey among 240 Indian students between the ages of 16 and 22 found that most of the students displayed poor money management skills as they spent most of their income on pleasure and fast food rather than on savings and books. It was further found that only half of the students utilised personal budgets and that female student had better money management skills than male students. French and McKillop (2016) argue that poor money management skills contribute to the high rate of indebtedness among individuals. Harrington et al. (2017) suggest that budgeting behaviours can be encouraged among business students by teaching them how to use low-effort personal budgets to avoid overspending.

While some studies have found that university students have good financial behaviour (Thapa, 2015), others have concluded that they do not (Allgood and Walstad, 2016; Chmelíková, 2016; Harrington et al., 2017). Chmelíková (2016) found that the experience of budgeting could influence the financial behaviour of university students. Poor financial behaviours such as overspending can be addressed by teaching and encouraging budgeting behaviours among university students (Harrington et al., 2017). Although Tang and Peter (2015) found a weak relationship between financial knowledge and financial behaviour and suggested that this could be due to parental influence and self-discipline, Shih and Ke (2014) found that general financial knowledge influences students' financial behaviours. Angus (2018) suggests that providing financial counselling to university students experiencing financial stress can produce positive results. Herawati et al. (2018) considered the effects of financial literacy, financial self-efficacy and the socioeconomic status of students' parents on the financial behaviours of accounting students in Bali, Indonesia. The study found all three variables to have a positive relationship with the students' financial behaviour.

Lusardi and Wallace (2013) on the other hand, highlight that being capable of making good financial decisions is dependent on quantitative literacy. This was found to be true among both high school students as well as university students in different countries such as the US, Romania, France, Switzerland, Australia, etc. Sadly, it has been found that numeracy capabilities among the general population worldwide are relatively low, with certain segments of the population such as the older generation, individuals with low academic qualifications, and women exhibiting particularly low levels (Lusardi, 2012). 
Literature provides evidence on how financial capability interacts with socio-demographics. These socio-demographics include gender, age, education, income, race, parent's income and parent's education. While Thapa (2015) found that there is no significant relationship between gender and financial capability, while Agnew and Harrison (2015) concluded that gender was the only consistent factor in understanding college students' debt behaviours in both New Zealand and England. This was similar to findings of some South African studies which found gender to be statistically significant among students studying accounting degrees in South African universities (De Clercq and Venter, 2009; Oseifuah and Gyekye, 2014). In addition, while Oseifuah and Gyekye (2014) further asserts that male students at the University of Limpopo are more financially capable than female, this finding was in contrast with (Fatoki, 2014), who found that female students enrolled in a non-business degree at two South African universities had better financial capability than their male counterparts.

Except for studies like Özdemir et al. (2015), most studies have found a positive relationship between college students' age and their financial capability (De Clercq and Venter, 2009; Xiao et al., 2015). In a study conducted among South African students studying to become Chartered Accountants, found that there is a positive relationship between age and financial decisions (De Clercq and Venter (2009). Xiao et al. (2015) found a positive relationship between age and financial capability. The study measured financial capability using five variables: objective financial literacy, subjective financial literacy, desirable financial behaviour, perceived financial capability and a financial capability index based on data from the US 2012 National Financial Capability Study. The youngest age group (18-24) exhibited the lowest score across all measures of financial capability.

Ansong and Gyensare (2012) found that levels of study and educational attainments do not influence the financial capability of university students in Ghana, while Shahrabani (2013) found that students studying economics and business-related degrees in Israel were much more financially inclined than their peers in other disciplines and concluded that a student's field of study can significantly affect his/her financial capability. Albeerdy and Gharleghi (2015a) found evidence of a strong relationship between the level of education and the financial literacy of college students in Malaysia. However, Botha (2013) asserted that there is no relationship between students' field of study and their financial capability. The author found that South African university students enrolled in both finance and nonfinance postgraduate diploma programmes had low levels of financial literacy. Likewise, Chmelíková (2016) concluded that students' financial capability was more influenced by their experience of financial decision making rather than their level of education and other socio-demographic factors.

De Clercq and Venter (2009) found that there is a positive relationship between income and the financial literacy of South African students studying to become Chartered Accountants. Ansong and Gyensare (2012) concluded that work experience influences students' personal financial decision making, as postgraduate students who earn an income independent of family sources exhibited better financial capability than those that depended on their parents. de Bassa Scheresberg (2013) found that financial capability is particularly low among young adults who are less educated and earn a lower income. This was based on a national study on the financial capability of more than 4500 individuals. Thapa (2015) asserts that students' income is a key factor in determining their financial capability. De Clercq and Venter (2009) found that there is a positive relationship between race and the financial literacy of South African students studying to become Chartered Accountants. Shahrabani (2013) found that Jewish students had better financial literacy than Arabian students. While the former had an overall mean score of $50 \%$, the latter only scored $39 \%$. The study further concludes that nationality influences financial decisionmaking capabilities. Agnew and Harrison (2015) found that New Zealand students are more financially literate than native English students. Serido et al. (2016) found that race and ethnicity are key determinants of financial capability

Botha (2013) found that parental income was a key determinant of the financial capability of South African students. Soria et al. (2014) concluded that undergraduate students from low-income backgrounds are susceptible to poor financial decisions. Herawati et al. (2018) suggested that financial literacy, financial self-efficacy and parents' economic status impact the financial behaviours of accounting students in Bali, Indonesia. Zhu (2018) discovered that the financial capability of economically disadvantaged adolescents is largely influenced by their poor economic circumstances as well as parental financial socialisation. While Ansong and Gyensare (2012) found that the mother's level of education can impact the financial capability of university students in Ghana, 
Tang and Peter (2015) suggest that the financial capability of young Americans is enhanced via the interaction of individual financial knowledge, financial experience and parental education. Hence, there is a positive relationship between parents' financial education and individual financial capability. Van Campenhout (2015) found that parental financial teaching goes a long way in the development of financial capability, and advocates for a re-evaluation of the parental role in financial socialisation within society.

Whilst the above literatures have considered financial capability in diverse contextual perspectives, there is yet no current study on the subject matter within the South African perspective. More precisely, it remains whether it is a generalisable fact that university students enrolled in financial courses, particularly accounting students in the KwaZulu-Natal Province of South Africa, will exhibit higher financial capability levels as measured by financial knowledge, financial attitudes, numeracy skills and financial behaviour.

Also, it is unclear what factors influence the financial capability of university students enrolled in financial courses, particularly accounting students in the KwaZulu-Natal Province of South Africa.

\section{DATA AND RESEARCH METHODOLOGY}

This research inquiry adopted a quantitative research approach, which used a questionnaire to elicit the necessary information on the financial capability of the Accounting students in KwaZulu-Natal universities. The structured questionnaire measured the levels and determinants of accounting students' financial capability, defined as financial knowledge, financial attitudes, financial behaviour and numeracy skills.

The adopted questionnaire was made up of 52 questions including demographic characteristics. It was divided into five broad categories, namely: Part A Socio-demographic characteristics; Part B - Financial Knowledge; Part C - Numeracy Skills; Part D Financial Attitudes; Part E - Financial Behaviour. Part
A of the questionnaire comprised of nine questions relating to gender, age, education, income, race, parents' income and parents education. Part B of the questionnaire comprised of sixteen questions relating to savings and investments, spending and credit, income, and money management. Part $\mathrm{C}$ of the questionnaire comprised of six questions relating to Numeracy skills. Part $D$ of the questionnaire comprised of eleven questions relating to Financial attitudes. Part $E$ of the questionnaire comprised of ten questions relating to Financial behaviour. The questions adopted for the study were adapted from existing studies such as (Mandell, 2004; Skagerlund et al., 2018).

The population for this study included all accounting students in KwaZulu-Natal universities enrolled in three-year undergraduate programmes on a full-time basis. This consisted of first-year, second-year and third-year students registered for the 2017/2018 academic year who are pursuing Bachelor of Commerce in Accounting, Bachelor of Commerce General and National Diploma in Accounting qualifications at the selected universities. Although there are four universities in KwaZulu-Natal, this study focused on three universities with the highest student enrolment. The selected universities were: University of KwaZulu-Natal (UKZN), Durban University of Technology (DUT) and Mangosuthu University of Technology (MUT). The fourth university (University of Zululand (UNIZULU)) was excluded due to difficulties experienced in gaining access to the students.

The study adopted both simple random and convenience sampling techniques, and a total sample size of 1582 questionnaires was considered valid for the study.

In order to effectively measure the study's results were grouped using ranges and analysed in line with previous studies as (Volpe et al., 1996; Mandell, 1998; Huston, 2010). However, considering that these studies were conducted in developed countries and that South Africa is a developing country, the score ranges were further adjusted as shown in Table 1.

Table 1: Capability/Knowledgeable Levels and Score Ranges

\begin{tabular}{|c|c|c|}
\hline Score Ranges & Adjusted score ranges & Financial Capability Levels \\
\hline \hline $80 \%$ and more & $65 \%$ and more & High financial capability \\
\hline $60 \%$ to $79 \%$ & $50 \%-64 \%$ & Moderate financial capability \\
\hline $59 \%$ and below & Below $50 \%$ & Low financial capability \\
\hline
\end{tabular}


Furthermore, in order to establish the levels of financial capability (financial knowledge, financial attitudes, financial behaviour and numeracy skills) among accounting students at universities in KwaZuluNatal. The study utilised data analysis methods such as Descriptive analysis, to examine the statistics of the data; Bivariate regression analysis, a type of statistical analysis that involves analysing two variables - in this case, socio-economic factors and financial capability; Cross-tabulations were used to analyse the relationship between financial capability and demographic variables, specifically level of study. The crosstabulations also enabled the results for one or more variables to be analysed and compared; One-way Analysis of Variance (ANOVA) was used to analyse group mean differences between socio-demographic variables and financial capability.

Also, in order to determine the intra-component drivers of financial capability among accounting students at universities in KwaZulu-Natal, the study utilised a Factor analysis model which employed analytical methods such as the Exploratory Factor Analysis (EFA) and Confirmatory Factor Analysis (CFA). While the Exploratory Factor Analysis (EFA) used multivariate statistics to detect the underlying structure of a relatively large number of variables of financial capability, the Confirmatory Factor Analysis (CFA) was used to test whether measures of a construct were consistent with the researcher's understanding of the financial capability factors (financial knowledge, numeracy skills, financial attitudes and financial behaviour).

\section{THE DATA ANALYSIS AND FINDINGS}

With a mean value of 1.12 and a standard deviation of 0.382 , the computation in Table 2 revealed that most of the accounting students have high financial capability levels, with a capability score of $89.5 \%$. The study also found that $8.6 \%$ of the respondents have moderate financial capability and only $1.9 \%$ exhibited a low level of financial capability. This depicts that accounting students are generally financially capable. However, these findings is in contrast to studies that have reported lower levels of financial capability among students and young adults (Mandell and Klein, 2009; Lin et al., 2016). Based on the descriptive analysis between the respondents' institutions and their financial capability, the results showed that $91.9 \%$ of the students from UKZN have high financial capability. This is followed by $90.4 \%$ of the students at MUT and $83.7 \%$ of the students at DUT. This breakdown is presented in Table 3.

\section{Respondents' Financial Knowledge}

As explicated in Table 4, the analysis of this study indicated that the majority of the respondents $(63.1 \%)$ are moderately financially knowledgeable, with only $14.5 \%$ highly financially knowledgeable and $22.4 \%$ less financially knowledgeable. While several recent studies have found low levels of financial knowledge among college students (Jayakumar et al., 2017; Andreou and Philip, 2018; Brooks and Wheeler, 2018; Anderson et al., 2018), others have suggested that these students have good financial knowledge (Sarpong-Danquah et

Table 2: Respondents' Financial Capability

\begin{tabular}{|c|c|c|}
\hline Competencies & Frequency & Percent \\
\hline \hline High Financial Capability & 1416 & 89.5 \\
\hline Moderate Financial Capability & 136 & 8.6 \\
\hline Low Financial Capability & 30 & 1.9 \\
\hline Total & 1582 & 100.0 \\
\hline
\end{tabular}

Table 3: Respondents' financial capability (FC) versus institutions

\begin{tabular}{|c|c|c|c|c|}
\hline \multirow{2}{*}{ Institutions } & \multicolumn{4}{|c|}{ Financial Capability (FC) } \\
\cline { 2 - 5 } & High FC & Moderate FC & $16(1.9 \%)$ & 864 \\
\hline \hline UKZN & $794(91.9 \%)$ & $54(6.3 \%)$ & $10(2.5 \%)$ & 404 \\
\hline DUT & $388(83.7 \%)$ & $56(13.9 \%)$ & $4(1.3 \%)$ & 314 \\
\hline MUT & $284(90.4 \%)$ & $26(8.3 \%)$ & $30(1.9 \%)$ & 1582 \\
\hline Total & $1416(89.5 \%)$ & $136(4.8 \%)$ & \multicolumn{2}{|c|}{ Lotal FC } \\
\hline
\end{tabular}


Table 4: Respondents' Financial Knowledge

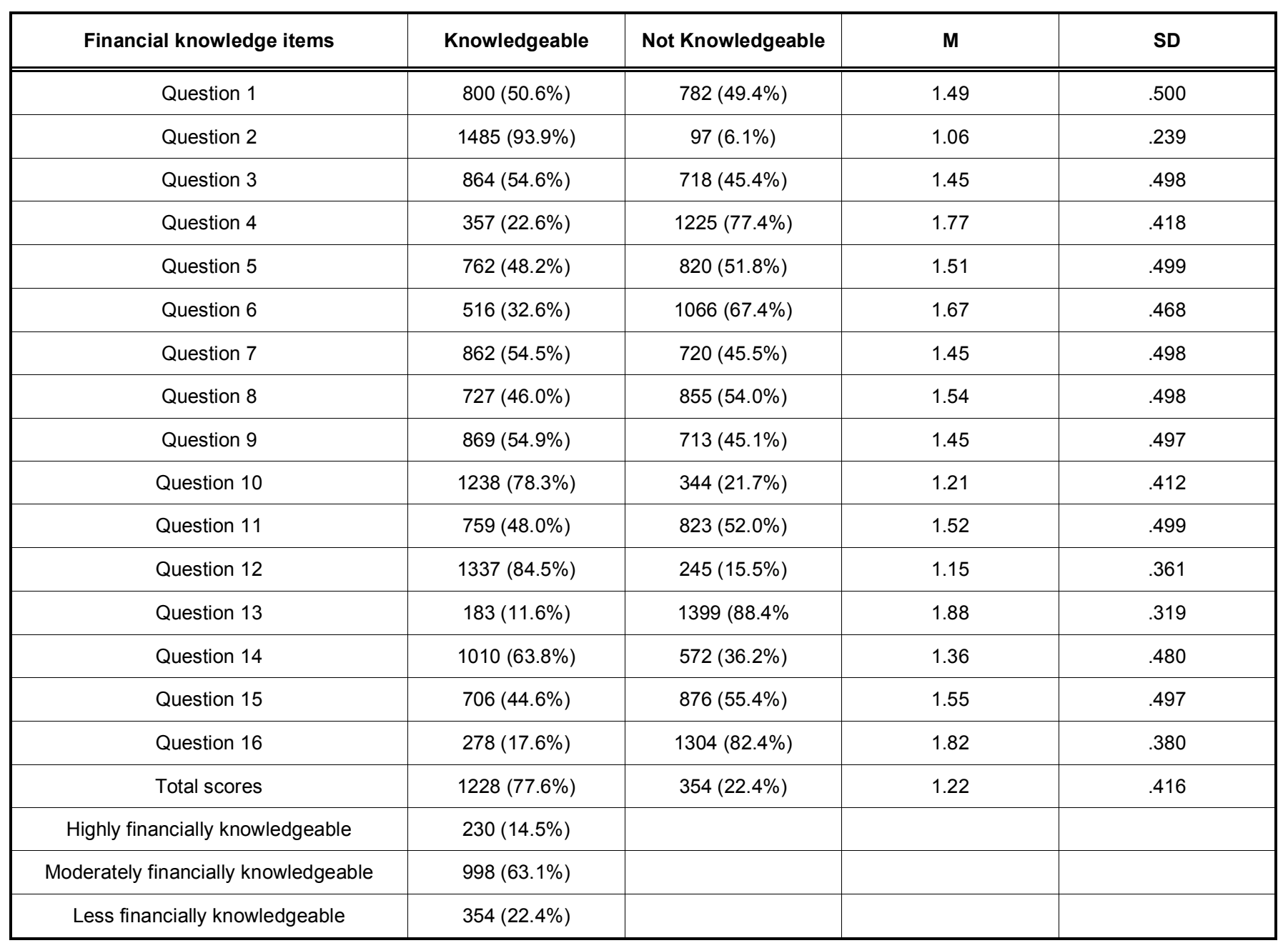

al., 2018). The findings of this study are similar to those of (Thapa, 2015), who found that college students in Nepal have a moderate level of basic financial knowledge at $62 \%$ mean score.

With considerations to savings and investment literacy, the analysis revealed that the majority of the respondents $(80.3 \%)$ have positive savings and investment literacy compared to $19.7 \%$ that do not. Although higher than the findings of existing studies, this is consistent with Amari and Jarboui (2015) and Thapa's (2015) studies which point to positive savings and investment literacy among college students. Furthermore, the analysis revealed that most of the respondents $(55.4 \%)$ are unable to manage their spending and credit as opposed to the $44.6 \%$ that are able to do so. This finding is consistent with those of other studies which indicate negative spending and credit literacy among college students (Thapa, 2015; Lusardi and Tufano, 2015; Brown et al., 2016; Chmelíková, 2016).
Again, $54.1 \%$ of the respondents exhibited good proficiency in managing their income as compared to $45.9 \%$ who displayed poor proficiency. This finding is inconsistent with the existing literature which points to poor income management literacy among college students (Harrison et al., 2015; Manju, 2016). With regard to money management literacy, the analysis shows that the majority of the respondents $(68.3 \%)$ can manage their money as opposed to $31.7 \%$ who are unable to do so. This finding is inconsistent with the existing literature which reveals poor income management literacy among college students (Harrison et al., 2015; Manju, 2016).

\section{Respondents' Financial Behaviour}

As shown in Table 5, based on the overall analysis conducted on all 10 items of financial behaviour, it was found that most of the respondents (81.3\%) have good financial behaviour as opposed to $18.7 \%$ that exhibit poor financial behaviour. While some studies have 
Table 5: Respondents' Financial Behaviour

\begin{tabular}{|c|c|c|c|c|}
\hline Financial Behaviour items & Good Behaviour & Poor Behaviour & $\mathbf{M}$ & SD \\
\hline Question 1 & $1329(84.0 \%)$ & $253(16.0 \%)$ & 1.15 & .366 \\
\hline Question 2 & $1302(82.3 \%)$ & $280(17.7 \%)$ & 1.17 & .381 \\
\hline Question 3 & $1325(83.8 \%)$ & $257(16.2 \%)$ & 1.16 & .368 \\
\hline Question 4 & $776(49.1 \%)$ & $806(50.9 \%)$ & 1.50 & .500 \\
\hline Question 5 & $611(38.6 \%)$ & $971(61.4 \%)$ & 1.61 & .487 \\
\hline Question 6 & $1125(71.1 \%)$ & $457(28.9 \%)$ & 1.28 & .453 \\
\hline Question 7 & $870(55.0 \%)$ & $712(45.0 \%)$ & 1.45 & .497 \\
\hline Question 8 & $949(60.0 \%)$ & $633(40.0 \%)$ & 1.40 & .490 \\
\hline Question 9 & $943(59.6 \%)$ & $639(40.4 \%)$ & 1.40 & .490 \\
\hline Question 10 & $1168(73.8 \%)$ & $414(26.2 \%)$ & 1.26 & .439 \\
\hline Total scores & $1286(81.3 \%)$ & $296(18.7 \%)$ & 1.18 & .390 \\
\hline
\end{tabular}

found that university students have good financial behaviour (Thapa, 2015), others have concluded that they do not (Allgood and Walstad, 2016; Chmelíková, 2016; Harrington et al., 2017).

\section{Respondents' Financial Knowledge vs Financial Behaviour}

With refernce to Table 6 , the analysis of financial knowledge indicated that of the 229 respondents that are highly financially knowledgeable, most exhibit good financial behaviour, with $(n=194 ; 84.7 \%)$. Again, the analysis indicated that most of the respondents $(n=813$; $81.4 \%$ ) that have moderate financial knowledge have good financial behaviour. However, the results also indicated that most of the respondents with less financial knowledge have good financial behaviour. This suggests that good financial behaviour is not necessarily an indication of being financially knowledgeable. Some studies agree that there is a positive relationship between financial knowledge and financial behaviour (Shih and Ke, 2014; Angus, 2018; Herawati et al., 2018). However, some studies have found otherwise (Mandell and Klein, 2009; Tang and Peter, 2015).

\section{Respondents' Financial Attitudes}

The overall analysis conducted on all 13 items of financial attitude as presented in Table 7, suggested that most of the respondents $(n=1513 ; 95.6 \%)$ have a positive financial attitude compared to the $(n=69 ; 4.4 \%)$ of the respondents who have a negative financial attitude. While this finding is consistent with some of the literature (Potrich et al., 2015; Isomidinova and Singh, 2017; Susan and Djajadikerta, 2017), some studies have asserted that college students and young adults, in general, have a negative financial attitude (Németh et al., 2015).

\section{Respondents' Numeracy Skills}

Based on the information contained in Table 8, the overall analysis conducted on all six items that tested numeracy skills among the students, the results suggested that most of the respondents $(n=1486$, $(93.9 \%)$ are numerically skilled. On the other hand, $(n=96 ; 6.1 \%)$ of the respondents are less numerically skilled. While this finding is consistent with some literature (Gao, 2017; Jayaraman et al., 2018), several studies have asserted that college students and young

Table 6: Respondents' Financial Knowledge vs Financial Behavior

\begin{tabular}{|c|c|c|}
\hline \multirow{2}{*}{ FINANCIAL KNOWLEDGE } & \multicolumn{2}{|c|}{ FINANCIAL BEHAVIOUR } \\
\cline { 2 - 3 } & Good Behaviour & Poor Behaviour \\
\hline \hline Highly Financial Knowledgeable & $194(84.7 \%)$ & $35(15.3 \%)$ \\
\hline Moderately Financially Knowledgeable & $813(81.4 \%)$ & $186(18.6 \%)$ \\
\hline Less Financially Knowledgeable & $279(78.8 \%)$ & $75(21.2 \%)$ \\
\hline Total & $1286(81.3 \%)$ & $296(18.7 \%)$ \\
\hline
\end{tabular}


Table 7: Respondents' Financial Attitude

\begin{tabular}{|c|c|c|c|c|}
\hline Financial Attitude items & Positive Attitude & Negative Attitude & M & SD \\
\hline Question 1 & $1518(96.0 \%)$ & $64(4.0 \%)$ & 1.04 & .197 \\
\hline Question 2 & $1511(95.5 \%)$ & $71(6.1 \%)$ & 1.04 & .207 \\
\hline Question 3 & $1405(88.8 \%)$ & $177(11.2 \%)$ & 1.11 & .315 \\
\hline Question 4 & $1224(77.4 \%)$ & $358(22.6 \%)$ & 1.22 & .418 \\
\hline Question 5 & $1203(76.0 \%)$ & $379(24.0 \%)$ & 1.23 & .426 \\
\hline Question 6 & $1357(85.8 \%)$ & $225(14.2 \%)$ & 1.14 & .349 \\
\hline Question 7 & $1440(91.0 \%)$ & $142(9.0 \%)$ & 1.08 & .285 \\
\hline Question 8 & $1305(82.5 \%)$ & $277(17.5 \%)$ & 1.17 & .380 \\
\hline Question 9 & $1262(79.8 \%)$ & $320(20.2 \%)$ & 1.20 & .401 \\
\hline Question 10 & $1396(88.2 \%)$ & $186(11.8 \%)$ & 1.11 & .322 \\
\hline Question 11 & $1484(93.8 \%)$ & $98(6.2 \%)$ & 1.06 & .241 \\
\hline Question 12 & $1304(82.4 \%)$ & $278(17.6 \%)$ & 1.17 & .380 \\
\hline Question 13 & $1406(88.9 \%)$ & $176(11.1 \%)$ & 1.11 & .314 \\
\hline Total scores & $1513(95.6 \%)$ & $69(4.4 \%)$ & 1.04 & .204 \\
\hline
\end{tabular}

adults, in general, have low levels of numeracy skills (Almenberg and Widmark, 2011; Fornero and Monticone, 2011; Lusardi and Wallace, 2013; French and McKillop, 2016). The results in this study contradict the majority of the literature reviewed and thus offer a different perspective on numeracy skills. When this study was undertaken, we anticipated that accounting students would have better numeracy skills, but we did not anticipate such a high level of numeracy.

\section{Intra-Component Drivers of Financial Capability}

The findings of this study suggest that three main factors influence accounting students' financial capability, namely, Financial Attitude; Financial Behavior; and Numeracy Skills. All these factors are significantly influential, with a $p$-value of $<0.05$ as depicted in Figure 1.
While some studies have shown that not all components of financial capability necessarily drive financial capability (Sherraden and Grinstein-Weiss, 2015; Xiao and O'Neill, 2016; Xiao and Porto, 2017; Drever et al., 2015), others have reported otherwise (Tang et al., 2015). The findings of this study are consistent with other studies that suggest a relationship between financial attitude, financial behaviour, numeracy skills and financial capability (Allgood and Walstad, 2016; Strömbäck et al., 2017). While some studies have established a link between financial knowledge and financial capability (Brown et al., 2014; Drever et al., 2015; Xiao and O'Neill, 2016; Xiao and Porto, 2017), this is not consistent with this study. The current study's finding that there is no link between financial knowledge and financial capability in the financial decision is supported by recent studies (Tang et al., 2015; Friedline and West, 2016).

Table 8: Respondents' Numerical Skills

\begin{tabular}{|c|c|c|c|c|}
\hline Financial knowledge items & Numerically skilled & Less numerically skilled & M & SD \\
\hline Question 1 & $1488(94.1 \%)$ & $94(5.9 \%)$ & 1.05 & .236 \\
\hline Question 2 & $1446(91.4 \%)$ & $136(8.6 \%)$ & 1.08 & .280 \\
\hline Question 3 & $1434(90.6 \%)$ & $148(9.4 \%)$ & 1.09 & .291 \\
\hline Question 4 & $472(29.8 \%)$ & $1110(70.2 \%)$ & 1.70 & .457 \\
\hline Question 5 & $1468(92.8 \%)$ & $114(7.2 \%)$ & 1.07 & .258 \\
\hline Question 6 & $990(62.6 \%)$ & $592(37.4 \%)$ & 1.37 & .484 \\
\hline Total scores & $1486(93.9 \%)$ & $96(6.1 \%)$ & 1.06 & .238 \\
\hline
\end{tabular}




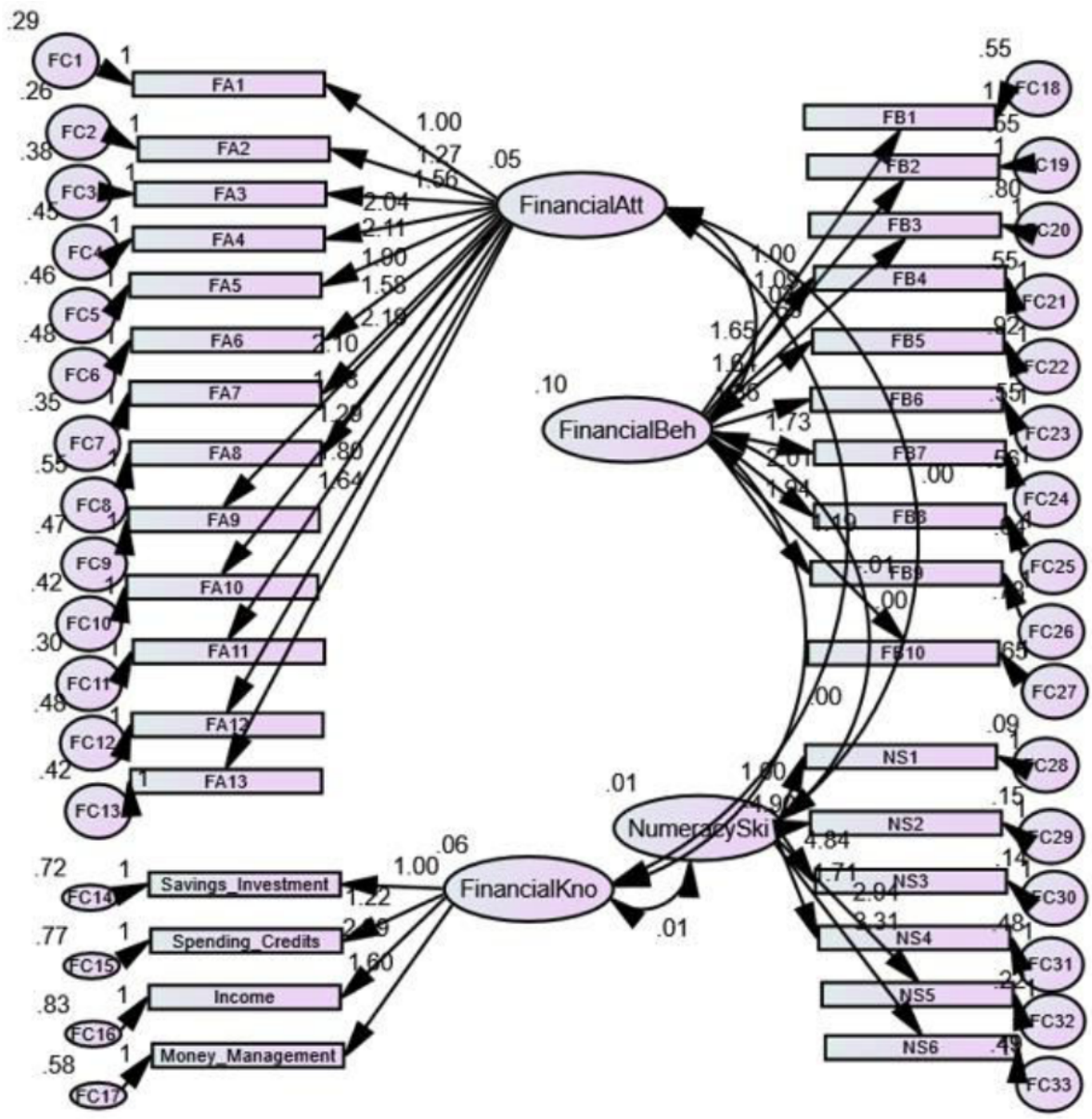

Figure 1: CFA path diagram (Financial Capability).

Socio-Demographic factors vs Financial capability.

Table 9: Regression Model of Financial Capability

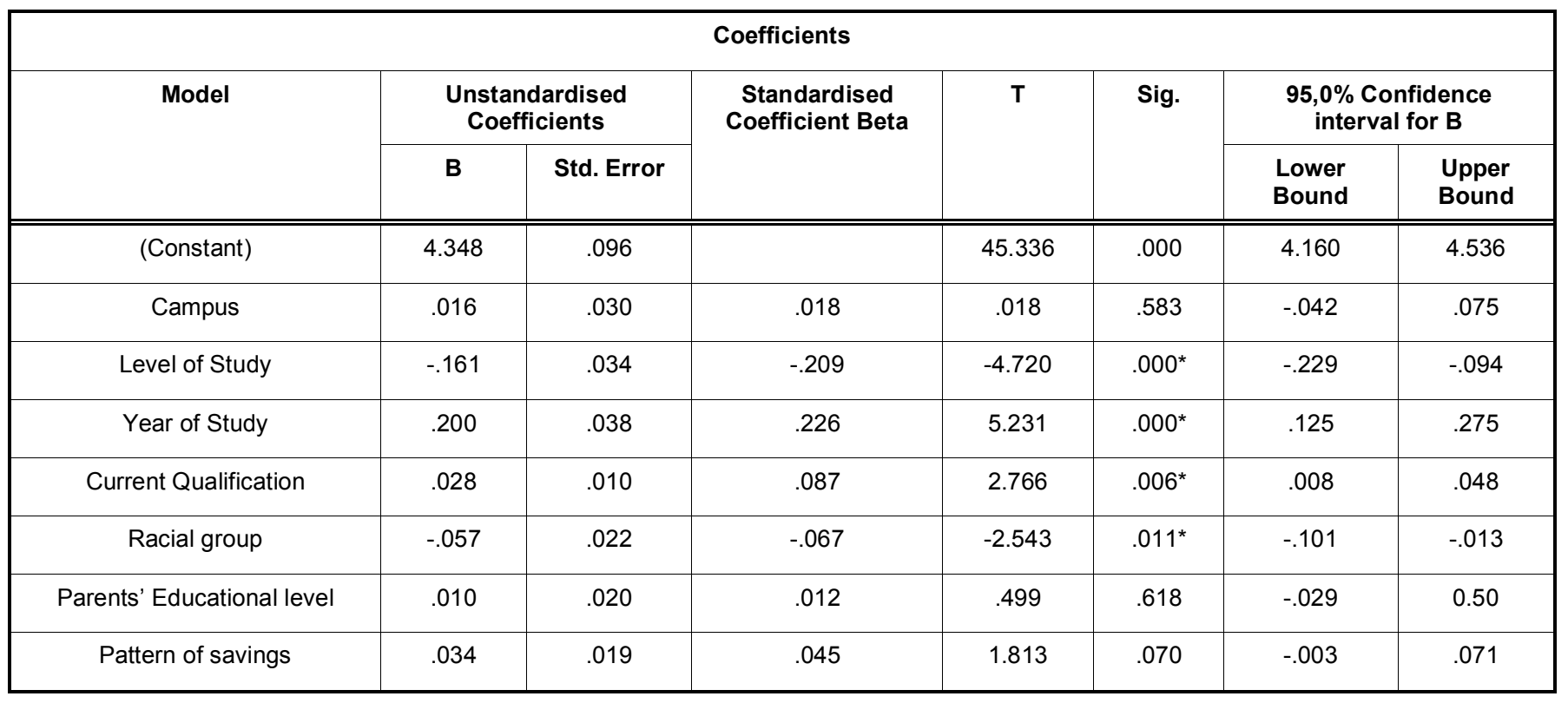

Dependent Variable: Financial Capability.

${ }^{*}=p<0.05$. 
Table 10: Bivariate Regression Model of Financial Capability

\begin{tabular}{|c|c|c|c|c|c|c|c|}
\hline \multicolumn{8}{|c|}{ Coefficients } \\
\hline Model & B & Std. Error & $\begin{array}{l}\text { Standardised } \\
\text { Coefficient Beta }\end{array}$ & $\mathbf{T}$ & Sig. & Lower Bound & Upper Bound \\
\hline (Constant) & 1.034 & .027 & & 38.922 & .000 & .982 & 1.086 \\
\hline Level of Study & -.069 & .017 & -.172 & -3.996 & .000 & -.103 & -.035 \\
\hline Current Qualification & .013 & .004 & .079 & 3.150 & .002 & .005 & .021 \\
\hline
\end{tabular}

Dependent Variable: Financial Capability.

\section{Gender}

Based on the results of the regression model in Table 9, Gender is not statistically significant in determining accounting students' financial capability. This finding is consistent with some existing studies (Thapa, 2015). However, other studies have found that there is a positive relationship between gender and financial capabilities (De Clercq and Venter, 2009; Oseifuah and Gyekye, 2014; Agnew and Harrison, 2015). Whilst several studies have concluded that male students are more financially capable than female students (Oseifuah and Gyekye, 2014; Montford and Goldsmith, 2016; Bucher-Koenen et al., 2017; Chen and Garand, 2018), a few have asserted that female students are better equipped to make financial decisions than male students (Shaari et al., 2013; Fatoki, 2014).

\section{Age}

Based on the results from the regression model in Table 9, Age is not statistically significant in determining accounting students' financial capability. Except for studies like Özdemir et al. (2015), most studies have found a positive relationship between college students' age and their financial capability (De Clercq and Venter, 2009; Xiao et al., 2015).

\section{Education}

Based on the results of the regression model in Tables 9 and 10, Education is statistically significant in determining accounting students' financial capability. For the purposes of this study, education comprised of students' level of study, year of study and current qualification. A breakdown of the students' financial capability and their institutions is further presented in Table 11.

This finding is consistent with some studies (Shahrabani, 2013; Fatoki, 2014; Albeerdy and Gharleghi, 2015b), but contradicts those of others that did not establish a relationship between education and financial capabilities (Ansong and Gyensare, 2012; Botha, 2013; Chmelíková, 2016; Motsepe, 2016).

\section{Income}

Based on the results from the regression model in Table 9, Income is not statistically significant in determining accounting students' financial capability. This finding is inconsistent with some studies (De Clercq and Venter, 2009; Ansong and Gyensare, 2012; de Bassa Scheresberg, 2013; Thapa, 2015).

\section{Race}

Based on the results from the regression model in Table 9, Race is statistically significant in determining accounting students' financial capability. This finding is consistent with existing studies which have reported that race influences financial capabilities (De Clercq and Venter, 2009; Shahrabani, 2013; Agnew and Harrison, 2015; Serido et al., 2016). However, some studies did not find a significant relationship between

Table 11: Respondents' Financial Capability (FC) Versus Institutions

\begin{tabular}{|c|c|c|c|c|}
\hline \multirow{2}{*}{ Institutions } & \multicolumn{4}{|c|}{ Financial Capability (FC) } \\
\cline { 2 - 5 } & High FC & Moderate FC & Low FC & $16(1.9 \%)$ \\
\hline \hline UKZN & $794(91.9 \%)$ & $54(6.3 \%)$ & $10(2.5 \%)$ & 404 \\
\hline DUT & $388(83.7 \%)$ & $56(13.9 \%)$ & $4(1.3 \%)$ & 314 \\
\hline MUT & $284(90.4 \%)$ & $26(8.3 \%)$ & $30(1.9 \%)$ & 1582 \\
\hline Total & $1416(89.5 \%)$ & $136(4.8 \%)$ & \multicolumn{2}{|c|}{ Total } \\
\hline
\end{tabular}


race and financial capabilities (Volpe et al., 1996; Chen and Volpe, 1998; Botha, 2013).

\section{Parents' Income}

Based on the results from the regression model in Table 9, Parents' income is not statistically significant in determining accounting students' financial capability. This finding is consistent with some studies (Mandell and Klein, 2007; Jorgensen and Savla, 2010). However, other studies have found that there is a positive relationship between parents' income and financial capability (Botha, 2013; Herawati et al., 2018; Zhu, 2018).

\section{Parents' Education}

Based on the results from the regression model in Table 9, Parents' education is not statistically significant in determining accounting students' financial capability. This finding is consistent with some studies (Albeerdy and Gharleghi, 2015b). However, other studies have found that there is a positive relationship between parents' education and financial capability (Ansong and Gyensare, 2012; Angulo-Ruiz and Pergelova, 2015; Németh et al., 2015; Tang and Peter, 2015).

\section{Level of Study vs Financial Capability}

As presented in Tables 9 and 10, the analysis suggested that most of the respondents from each class have the high financial capability. The majority of the 180 respondents from first-year non-accounting specialisation have the high financial capability, with ( $\mathrm{n}$ $=151 ; 83.9 \%$ ). Similarly, most of the 579 respondents from first-year mainstream have the high financial capability, with ( $n=528 ; 91.2 \%$ ). Moreover, the majority of the 470 respondents in their second year of study have the high financial capability, with $(n=428 ; 91.1 \%)$ as do most of the 353 respondents in their third year of study, with $(n=309 ; 87.5 \%)$. Hence, there is a statistically significant relationship between the predicting variables (level of study, current qualification, and year of study) and the outcome variable (financial capability) - the level of study, current qualification, and year of study were used to predict financial capability among accounting students. These findings are inconsistent with related studies on the financial literacy of students (Ansong and Gyensare, 2012; Botha, 2013; Chmelíková, 2016; Motsepe, 2016). However, they are consistent with the findings of other studies (Shahrabani, 2013; Fatoki, 2014; Albeerdy and Gharleghi, 2015b).
The findings of this study as discussed is this section, highlights significant evidences on the financial capability of South African students in comparison with existing literatures globally.

\section{CONCLUSION}

The study found that accounting students within KwaZulu-Natal are highly financially capable with a percentage of financial capability mean score of $89.5 \%$. The results from cross-tabulations between the students' universities and their financial capability, further highlight that students from UKZN are the most financially capable with $91.9 \%$ of the total sample being highly financially capable. This was followed by students from MUT (90.4\%), then DUT (83.7\%). An analysis of the intra-component drivers of financial capability suggests that three main factors influence accounting students' financial capability, namely, Financial Attitude; Financial Behavior; and Numeracy Skills. All these factors are significantly influential, with a $p$-value of $<0.05$. It has been said that financial capability can improve both financial decisions making as well as access to suitable financial products and services, which are the two defining elements of financial inclusion. This view is in consonance with the combined capability approach, which posits that both internal capacity and external conditions are necessary to affect the capability of individuals. This study provides insight into the understanding of the financial capability of students and young adults in KwaZuluNatal, South Africa. The provided empirical evidence is relevant in better understanding the financial decisionmaking capabilities of this group as well as factors that crucial to the improvement of their financial capabilities.

\section{APPENDIX A - FINANCIAL CAPABILITY OF ACCOUNTING STUDENTS IN SOUTH AFRICAN UNIVERSITIES}

\section{Financial Knowledge - Questions (Read in Conjuction with Table 4)}

Question 1 - Income question

Question 2 - Savings and Investment question

Question 3 - Savings and Investment question

Question 4 - Spending and Credit question

Question 5 - Income question

Question 6 - Savings and Investment question 
Question 6 - Spending and Credit question

Question 7 - Savings and Investment question

Question 8 - Money management question

Question 9 - Money management question

Question 10 - Income question

Question 11 - Savings and Investment question

Question 12 - Money management question

Question 13 - Income question

Question 14 - Income question

Question 15 - Spending and Credit question

Question 16 - Spending and Credit question

Financial Behaviour - Questions (Read in Conjuction with Table 5)

Question 1 - Financial organization question

Question 2 - Financial discipline question

Question 3 - Financial organization question

Question 4 - Financial organization question

Question 5 - Financial organization question

Question 6 - Financial discipline question

Question 7 - Financial discipline question

Question 8 - Financial discipline question

Question 9 - Financial risk question

Question 10 - Finanacial risk question

\section{Financial Attitudes - Questions (Read in Conjuction with Table 7)}

Question 1 - Financial responsibility question

Question 2 - Financial descipline question

Question 3 - Financial Motivation and control question

Question 4 - Financial responsibility question

Question 5 - Financial responsibility question

Question 6 - Financial responsibility question
Question 7 - Financial descipline question

Question 8 - Financial Motivation and control question

Question 9 - Financial responsibility question

Question 10 - Financial Motivation and control question

Question 11 - Financial Descipline question

Question 12 - Financial Motivation and control

Question 13 - Financial Motivation and control

\section{Numeracy Skills - Questions (Read in Conjuction with Table 8)}

Question 1 - Subtraction question

Question 2 - Multiplication question

Question 3 - Propability question

Question 4 - Fraction question

Question 5 - Division question

Question 6 - Compound Interest question

NB: This appendix explains better the type of questions that were used during data collection.

\section{REFERENCES}

Agnew S and Harrison N. (2015) Financial literacy and student attitudes to debt: A cross national study examining the influence of gender on personal finance concepts. Journal of Retailing and Consumer Services 25: 122-129. https://doi.org/10.1016/j.jretconser.2015.04.006

Albeerdy MI and Gharleghi B. (2015) Determinants of the financial literacy among college students in Malaysia. International Journal of Business Administration 6: 15-24. https://doi.org/10.5430/ijba.v6n3p15

Allgood S and Walstad WB. (2016) The effects of perceived and actual financial literacy on financial behaviors. Economic inquiry 54: 675-697. https://doi.org/10.1111/ecin.12255

Almenberg $\mathrm{J}$ and Widmark O. (2011) Numeracy, financial literacy and participation in asset markets. Available at SSRN 1756674.: 40 https://doi.org/10.2139/ssrn.1756674

Amari M and Jarboui A. (2015) Financial literacy and economics education among young adults: An observation from Tunisia. Journal of Business \& Finance Librarianship 20: 209-219. https://doi.org/10.1080/08963568.2015.978834

Anderson DM, Conzelmann JG and Lacy TA. (2018) The state of financial knowledge in college: New evidence from a national survey. RAND working papers: 1-41. https://doi.org/10.7249/WR1256

Andreou PC and Philip D. (2018) Financial knowledge among university students and implications for personal debt and fraudulent investments. Cyprus Economic Policy Review, Forthcoming 12: 3-23. https://doi.org/10.2139/ssrn.3250850 
Angulo-Ruiz F and Pergelova A. (2015) An empowerment model of youth financial behavior. Journal of Consumer Affairs 49: 550-575. https://doi.org/10.1111/joca.12086

Angus R. (2018) A Case Study of Why it is Important to Provide Financial Counselling for Vulnerable Students at University. JANZSSA-Journal of the Australian and New Zealand Student Services Association 26: 37-82. https://doi.org/10.30688/janzssa.2018.08

Ansong A and Gyensare MA. (2012) Determinants of university working-students' financial literacy at the University of Cape Coast, Ghana. International Journal of Business and Management 7: 126. https://doi.org/10.5539/ijbm.v7n9p126

Banerjee MM, Friedline T and Phipps BJ. (2017) Financial capability of parents of kindergarteners. Children and Youth Services Review 81: 178-187. https://doi.org/10.1016/i.childyouth.2017.08.009

Botha M. (2013) A comparative analysis of the financial literacy of final year diploma students in different fields of study at the University of Johannesburg. University of Johannesburg, 131.

Brooks C and Wheeler B. (2018) Establishing the Effect of Financial Knowledge, Financial Well-being, Self-Esteem, and Locus of Control on Financial Distress among University Students.

Brown A, Collins JM, Schmeiser M, et al. (2014) State mandated financial education and the credit behavior of young adults. 41. https://doi.org/10.2139/ssrn.2495884

Brown M, Grigsby J, van der Klaauw W, et al. (2016) Financial education and the debt behavior of the young. The Review of Financial Studies 29: 2490-2522. https://doi.org/10.1093/rfs/hhw006

Bucher-Koenen T, Lusardi A, Alessie R, et al. (2017) How financially literate are women? An overview and new insights. Journal of Consumer Affairs 51: 255-283. https://doi.org/10.1111/joca.12121

Chen H and Volpe RP. (1998) An analysis of personal financial literacy among college students. Financial Services Review 7: 107-128. https://doi.org/10.1016/S1057-0810(99)80006-7

Chen Z and Garand JC. (2018) On the Gender Gap in Financial Knowledge: Decomposing the Effects of Don't Know and Incorrect Responses. Social Science Quarterly 99: 15511571. https://doi.org/10.1111/ssqu.12520

Chmelíková B. (2016) Financial Decision-Making among Finance Students: An Empirical Study from the Czech Republic. Self 498: 49-52.

de Bassa Scheresberg C. (2013) Financial literacy and financial behavior among young adults: Evidence and implications. Numeracy 6: 5-21 https://doi.org/10.5038/1936-4660.6.2.5

De Clercq B and Venter J. (2009) Factors influencing a prospective chartered accountant's level of financial literacy: an exploratory study. Meditari Accountancy Research 17: 47-60. https://doi.org/10.1108/10222529200900011

Drever Al, Odders-White E, Kalish CW, et al. (2015) Foundations of financial well-being: Insights into the role of executive function, financial socialization, and experience-based learning in childhood and youth. Journal of Consumer Affairs 49: 13-38. https://doi.org/10.1111/joca.12068

Fatoki O. (2014) The Financial literacy of non-business university students in South Africa. International Journal of Educational Sciences 7: 261-267. https://doi.org/10.1080/09751122.2014.11890188
Fornero E and Monticone C. (2011) Financial literacy and pension plan participation in Italy. Journal of Pension Economics \& Finance 10: 547-564. https://doi.org/10.1017/S1474747211000473

French D and McKillop D. (2016) Financial literacy and overindebtedness in low-income households. International Review of Financial Analysis 48: 1-11. https://doi.org/10.1016/j.irfa.2016.08.004

Friedline T and West S. (2016) Financial education is not enough: Millennials may need financial capability to demonstrate healthier financial behaviors. Journal of Family and Economic Issues 37: 649-671. https://doi.org/10.1007/s10834-015-9475-y

Gao T. (2017) Numeracy, Financial Literacy, and Investment Behaviors. The Ohio State University, 54.

Harrington C, Smith W and Bauer R. (2017) Influencing business student intent to use a personal budget. The Accounting Educators' Journal 26: 135-153.

Harrison N, Chudry F, Waller R, et al. (2015) Towards a typology of debt attitudes among contemporary young UK undergraduates. Journal of Further and Higher Education 39: 85-107.

https://doi.org/10.1080/0309877X.2013.778966

Herawati NT, Candiasa IM, Yadnyana IK, et al. (2018) Factors That Influence Financial Behavior Among Accounting Students in Bali. International Journal of Business Administration 9: 30. https://doi.org/10.5430/ijba.v9n3p30

Huston SJ. (2010) Measuring financial literacy. Journal of Consumer Affairs 44: 296-316. https://doi.org/10.1111/j.1745-6606.2010.01170.x

Isomidinova $G$ and Singh JSK. (2017) Determinants of financial literacy: a quantitative study among young students in Tashkent, Uzbekistan. Electronic Journal of Business \& Management 2: 61-75.

Jayakumar KL, Larkin DJ, Ginzberg S, et al. (2017) Personal financial literacy among US medical students. MedEdPublish 6: 1-20. https://doi.org/10.15694/mep.2017.000035

Jayaraman J, Jambunathan S and Counselman K. (2018) The Connection between Financial Literacy and Numeracy: A Case Study from India. Numeracy 11: 5-21. https://doi.org/10.5038/1936-4660.11.2.5

Johnson E and Sherraden MS. (2007) From Financial Literacy to Financial Capability smong Youth. J. Soc. \& Soc. Welfare 34: 119-146.

Jorgensen BL and Savla J. (2010) Financial literacy of young adults: The importance of parental socialization. Family Relations 59: 465-478. https://doi.org/10.1111/j.1741-3729.2010.00616.x

Lin JT, Bumcrot C, Ulicny T, et al. (2016) Financial capability in the United States 2016. Washington, DC: FINRA Investor Education Foundation: 1-37.

Loke V, Choi L and Libby M. (2015) Increasing youth financial capability: An evaluation of the MyPath savings initiative. Journal of Consumer Affairs 49: 97-126. https://doi.org/10.1111/joca.12066

Lusardi A. (2011) Americans' financial capability. National Bureau of Economic Research, 1-26. https://doi.org/10.3386/w17103

Lusardi A. (2012) Numeracy, financial literacy, and financial decisionmaking. National Bureau of Economic Research, 1-25. https://doi.org/10.3386/w17821

Lusardi A and Mitchell OS. (2014) The economic importance of financial literacy: Theory and evidence. Journal of economic literature 52: 5-44. https://doi.org/10.1257/jel.52.1.5 
Lusardi A and Tufano P. (2015) Debt literacy, financial experiences, and overindebtedness. Journal of Pension Economics \& Finance 14: 332-368. https://doi.org/10.1017/S1474747215000232

Lusardi A and Wallace D. (2013) Financial literacy and quantitative reasoning in the high school and college classroom. Numeracy 6: 1-7. https://doi.org/10.5038/1936-4660.6.2.1

Mandell L. (1998) Our vulnerable youth: The financial literacy of American 12th graders: Jump $\$$ tart Coalition for Personal Financial Literacy : 1-24.

Mandell L. (2004) Financial Literacy Improves Among Nation's High School Students. Jump \$ tar Questionnaire for Seniors Reveals Moderate Gains, 16-29.

Mandell L and Klein L. (2009) The impact of financial literacy education on subsequent financial behavior. Journal of Financial Counseling and Planning:20: 1-36.

Mandell L and Klein LS. (2007) Motivation and financial literacy. Financial services review 16: 1-18.

Manju R. (2016) Trends in Spending and Money Management Practices among Students of Kerala. International Journal of Research 39: 39-47.

Mitton L. (2008) Financial inclusion in the UK: Review of policy and practice: Joseph Rowntree Foundation York.

Montford W and Goldsmith RE. (2016) How gender and financial self-efficacy influence investment risk taking. International Journal of Consumer Studies 40: 101-106. https://doi.org/10.1111/ijcs.12219

Motsepe L. (2016) Exploring financial literacy amongst first year university students: a case study of Howard College, University of KwaZulu-Natal. 1-104.

Németh E, Béres D and Huzdik K. (2015) The Attitude of Young Hungarian Adults to Loans. International Journal of Business and Social Science 6: 63-73.

Nga K and Yeoh K. (2015) Affective, Social and Cognitive Antecedents of Attitude towards Money among Undergraduate Students: A Malaysian Study. Pertanika Journal of Social Sciences \& Humanities 23: 161-180.

Nussbaum M. (2000) Women's capabilities and social justice. Journal of human development 1: 219-247. https://doi.org/10.1080/713678045

Nussbaum M and Sen A. (1993) The quality of life: Oxford University Press: 1-445. https://doi.org/10.1093/0198287976.003.0001

Nussbaum MC. (2011) Creating capabilities: Harvard University Press: $1-362$ https://doi.org/10.4159/harvard.9780674061200

Oseifuah EK and Gyekye AB. (2014) Analysis of the Level of Financial Literacy among South African Undergraduate Students. Journal of Economics and Behavioral Studies 6: 48-65. https://doi.org/10.22610/jebs.v6i3.487

Özdemir A, Temizel F, Sönmez H, et al. (2015) Financial literacy of university students: A case study for anadolu university, Turkey. Uluslararası Yönetim Iktisat ve İşletme Dergisi 11: 97-110.

https://doi.org/10.17130/ijmeb.2015.11.24.815

Potrich ACG, Vieira KM, Coronel DA, et al. (2015) Financial literacy in Southern Brazil: Modeling and invariance between genders. Journal of Behavioral and Experimental Finance 6: 1-12. https://doi.org/10.1016/j.jbef.2015.03.002

Rawls J. (2009) A theory of justice: Harvard university press: 1-377. https://doi.org/10.2307/j.ctvkjb25m

Robeyns I. (2005) The capability approach: a theoretical survey. Journal of human development 6: 93-117. https://doi.org/10.1080/146498805200034266
Robeyns I. (2006) The capability approach. Handbook of economics and ethics 39: 351-376. https://doi.org/10.1111/j.1467-9760.2006.00263.x

Robeyns I. (2016) Capabilitarianism. Journal of Human Development and Capabilities 17: 397-414. https://doi.org/10.1080/19452829.2016.1145631

Sarpong-Danquah B, Gyimah P, Poku K, et al. (2018) Financial Literacy Assessment on Tertiary Students in Sub-Saharan Africa: A Ghanaian Perspective. International Journal of Accounting and Financial Reporting 8: 76-91. https://doi.org/10.5296/ijafr.v8i2.12928

Sen A. (1987) Gender and cooperative conflicts: Wider Helsinki: 1354.

Sen A. (1993) Capability and well-being73. The quality of life 30: 1445. https://doi.org/10.1093/0198287976.003.0003

Serido J, Cities T, Deenanath V, et al. (2016) The Financial Behavior of First-Year College Students: The Power of Parenting and Self-Efficacy. Consumer Interests Annual 62: 1457-1470.

Shaari NA, Hasan NA, Mohamed R, et al. (2013) Financial literacy: A study among the university students. Interdisciplinary journal of contemporary research in business 5: 279-299.

Shahrabani S. (2013) Financial literacy among Israeli college students. Journal of College Student Development 54: 439446. https://doi.org/10.1353/csd.2013.0063

Sherraden MS. (2013) Building blocks of financial capability. Financial education and capability: Research, education, policy, and practice: 3-43. https://doi.org/10.1093/acprof:oso/9780199755950.003.0012

Sherraden MS and Grinstein-Weiss M. (2015) Creating financial capability in the next generation: An introduction to the special issue. Journal of Consumer Affairs 49: 1-12. https://doi.org/10.1111/joca.12067

Sherraden MS, Huang J, Frey JJ, et al. (2015) Financial capability and asset building for all. American Academy of Social Work and Social Welfare: 1-29.

Shih T-Y and Ke S-C. (2014) Determinates of financial behavior: insights into consumer money attitudes and financial literacy. Service Business 8: 217-238. https://doi.org/10.1007/s11628-013-0194-x

Skagerlund K, Lind T, Strömbäck C, et al. (2018) Financial literacy and the role of numeracy-How individuals' attitude and affinity with numbers influence financial literacy. Journal of behavioral and experimental economics 74: 18-25. https://doi.org/10.1016/j.socec.2018.03.004

Soria KM, Weiner B and Lu EC. (2014) Financial decisions among undergraduate students from low-income and working-class social class backgrounds. Journal of Student Financial Aid 44(1):1- 23.

Strömbäck C, Lind T, Skagerlund K, et al. (2017) Does self-control predict financial behavior and financial well-being? Journal of Behavioral and Experimental Finance 14: 30-38. https://doi.org/10.1016/j.jbef.2017.04.002

Susan M and Djajadikerta H. (2017) Understanding Financial Knowledge, Financial Attitude, and Financial Behavior of College Students in Indonesia. Advanced Science Letters 23: 8762-8765. https://doi.org/10.1166/asl.2017.9966

Tang N, Baker A and Peter PC. (2015) Investigating the disconnect between financial knowledge and behavior: The role of parental influence and psychological characteristics in responsible financial behaviors among young adults. Journal of Consumer Affairs 49: 376-406. https://doi.org/10.1111/joca. 12069

Tang $\mathrm{N}$ and Peter PC. (2015) Financial knowledge acquisition among the young: The role of financial education, financial experience, and parents' financial experience. Financial Services Review 24: 119. 
Thapa BS. (2015) Financial literacy in Nepal: A survey analysis from college students. NRB Economic Review 27: 49-74.

Van Campenhout G. (2015) Revaluing the role of parents as financial socialization agents in youth financial literacy programs. Journal of Consumer Affairs 49: 186-222. https://doi.org/10.1111/joca.12064

Volpe RP, Chen H and Pavlicko JJ. (1996) Personal investment literacy among college students: A survey. Financial Practice and Education 6: 86-94.

West $S$ and Friedline T. (2016) Coming of age on a shoestring budget: Financial capability and financial behaviors of lowerincome millennials. Social work 61: 305-312. https://doi.org/10.1093/sw/sww057

Xiao JJ, Chen C and Sun L. (2015) Age differences in consumer financial capability. International Journal of Consumer Studies 39: 387-395.

https://doi.org/10.1111/ijcs.12205
Xiao JJ and O'Neill B. (2016) Consumer financial education and financial capability. International Journal of Consumer Studies 40: 712-721. https://doi.org/10.1111/ijcs.12285

Xiao JJ and Porto N. (2017) Financial education and financial satisfaction: Financial literacy, behavior, and capability as mediators. International Journal of Bank Marketing 35: 805817. https://doi.org/10.1108/IJBM-01-2016-0009

Zhu AYF. (2018) Links Between Family Poverty and the Financial Behaviors of Adolescents: Parental Roles. Child Indicators Research: 1-15.

Zottel SP, Valeria; Bolaji-Adio, Adedayo. (2013) Financial capability surveys around the World: why financial capability is important and how surveys can help. World Bank: 1-8.

Received on 10-01-2020

Accepted on 20-02-2020

Published on 04-06-2020

DOI: https://doi.org/10.6000/1929-7092.2020.09.19

(c) 2020 Nomlala and Sibanda; Licensee Lifescience Global.

This is an open access article licensed under the terms of the Creative Commons Attribution Non-Commercial License (http://creativecommons.org/licenses/by-nc/3.0/) which permits unrestricted, non-commercial use, distribution and reproduction in any medium, provided the work is properly cited. 